\title{
Mitral regurgitation and other valvular heart diseases
}

\author{
(1)Ante Pašalićc ${ }^{*}$, \\ - Leon Adrović', \\ (1)Tea Friščić', \\ OZrinka Planinić', \\ OMarko Perčić', \\ (1)Dario Gulin', \\ DDijana Bešić', \\ (1) Jozica Šikić1,2
}

'University Hospital “Sveti Duh", Zagreb, Croatia

2University of Zagreb School of Medicine, Zagreb, Croatia
KEYWORDS: mitral regurgitation, aortic stenosis, aortic regurgitation, tricuspid regurgitation. CITATION: Cardiol Croat. 2018;13(5-6):185. | https://doi.org/10.15836/ccar2018.185

*ADDRESS FOR CORRESPONDENCE: Ante Pašalić, Klinička bolnica "Sveti Duh“, Sv. Duh 64, HR-10000 Zagreb, Croatia. / Phone: +385-91-3712-083 / E-mail: ante.pasalic@outlook.com

ORCID: Ante Pašalić, https://orcid.org/0000-0001-5989-6495 • Leon Adrović, https://orcid.org/0000-0002-0555-6863 Tea Friščić, https://orcid.org/0000-0003-3189-8661 • Zrinka Planinić, https://orcid.org/0000-0001-8664-3338 Marko Perčić, https://orcid.org/0000-0001-7904-8899 • Dario Gulin, https://orcid.org/0000-0001-8502-7816 Dijana Bešić, https://orcid.org/0000-0001-9701-0253• Jozica Šikić, https://orcid.org/0000-0003-4488-0559

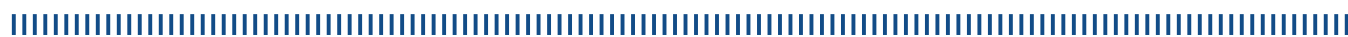

Background: Mitral regurgitation (MR) represents the second most common valvular heart disease (VHD), with incidence of $24 \%^{1} .10,4 \%$ of patients have two and $0.8 \%$ three or more concurrent valvular heart disease ${ }^{1}$. MR can be isolated or associated with other valvular heart disease, most commonly with tricuspid regurgitation ${ }^{2}$. In this article we represent data from our centre.

Patients and Methods: Retrospective study was conducted to assess the relation between MR with other VHD. A total of 686 patients, with male predominance of $55 \%$, were included in the study. The patients were divided into four groups according to the number of valvular diseases: two, three and four valvular diseases.

Results: Among the patients with two valvular disease, the most common combination was MR and tricuspid regurgitation (TR) (50.58\%). Among the patients with three valvular disease, the combination of MR, aortic regurgitation (AR) and TR was the most common. (17.78\%). Finally, four valvular disease was found in $5.98 \%$ of patients. In both men and women with two valvular disease, MR and TR, was most frequently found (44.3 and 58.3\%) in contrast to MR and AS which was least common combination (16.7 and 26.2\%) in both men and women. When it comes to three valvular disease combination of MR, aortic stenosis (AS) and AR or MR, AS and TR was almost the same.

Conclusion: Our results match the above-mentioned results in general population. MR was most commonly associated with TR. In three valvular disease combinations of MR, AR and TR was the most common in both gender.
RECEIVED:

May 3, 2018

ACCEPTED:

May 10, 2018

1. Andell P, Li X, Martinsson A, Andersson C, Stagmo M, Zöller B, et al. Epidemiology of valvular heart disease in a Swedish nationwide hospitalbased register study. Heart. 2017 Nov;103(21):1696-1703. https://doi.org/10.1136/heartjnl-2016-310894

2. Zamorano JL, Manuel Monteagudo J, Mesa D, Gonzalez-Alujas T, Sitges M, Carrasco-Chinchilla F, et al. Frequency, Mechanism and Severity of Mitral Regurgitation: Are There any Differences Between Primary and Secondary Mitral Regurgitation? J Heart Valve Dis. 2016 Nov:25(6):724729. PubMed: https://www.ncbi.nlm.nih.gov/pubmed/28290172 